\title{
External Debt and Economic Growth in Nigeria: Long Run Analysis
}

\author{
Paul Ndubuisi \\ Department of Banking and Finance, Abia State University, Uturu, Nigeria \\ Email address: \\ pauloabsu2017@gmail.com

\section{To cite this article:} \\ Paul Ndubuisi. External Debt and Economic Growth in Nigeria: Long Run Analysis. International Journal of Finance and Banking \\ Research. Vol. 5, No. 6, 2019, pp. 180-187. doi: 10.11648/j.ijfbr.20190506.17
}

Received: September 29, 2019; Accepted: October 28, 2019; Published: December 25, 2019

\begin{abstract}
The role of external debt in economic growth of developing countries has been questioned since there has been a high incidence of default, low economic growth and high levels of poverty, all of which are associated with high stocks of external debt. Also, the uncertainties about country external debt sustainability position as well as whether countries are already trapped in the debt-overhang situation have underlined point of debate among scholars. This study investigates the dynamic relationship between external debt and economic growth of Nigeria for period of 1985 to 2017 using Johansen approach to cointegration, vector error correction model (VECM) and granger causality test. Data for the study was collected from the CBN statistical bulletin. The findings revealed that debt service payment has negative and insignificant impact on Nigeria's economic growth while external debt stock has negative and significant effect on economic growth. The causality test indicates no-directional causality between external debt and GDP. From the findings, the study recommends that policy-makers should reformulate the external debt management strategy to minimize sovereign risk through diversification of the external borrowing. This could potentially be achieved by reducing the dependency on one specific debt instrument or currency. Hence, the strategy will be effective if it is carried out in parallel with a comprehensive surveillance and debt-monitoring system.
\end{abstract}

Keywords: Conomic Growth, External Debt, Dependency Theory, Debt Servicing, Exchange Rate

\section{Introduction}

In late decades, studies on economic growth and its determinants has pulled in significant consideration. Be that as it may, studies on external debt on economic growth are as yet falling behind, prompting equivocal answers. The increasing level of stock of debt has raised worries about whether the external debt borrowing could help to boast economic growth or whether it could turn into a burden that future would need to pay for. Likewise, the role of external debt in economic growth of developing countries has been questioned since there has been a high incidence of default, low economic growth and high levels of poverty, all of which are associated with high stocks of external debt. Furthermore, the uncertainties about country external debt sustainability position as well as whether countries are already trapped in the debt-overhang situation have underlined the importance of analyzing this issue. Besides, the vulnerabilities about nation external debt manageability position just as regardless of whether nations are as of now caught in the debt overhang circumstance have underlined the significance of investigating this issue. Because of rare assets in household economies, external debt has turned out to be one of the significant wellsprings of household capital. Specifically, that explains the savings gap and foreign exchange gap, has highlighted the motivation behind the introduction of external debt to a growth model. The savings gap and foreign exchange gap indicate that there are inadequate and insufficient resources to support the expected level of growth in the economy, revealing the role of external borrowings. Thus, the role of external borrowing in economic growth has been discovered even though it depends on the two gaps of either savings investment or import-export. MohdDauda, Ahmad and Azman-Saini (2013) the foreign borrowing will increase until the gaps are narrowed and the expected marginal product of capital is equivalent to the marginal cost of funds [1].

In addition, increase borrowing in the domestic economy can crowd out private sector investment. Further, research has shown that public debt levels have a non-linear impact on growth. Reinhart and Rogoff, (2010) found that public debt to 
GDP in excess country's threshold would have a negative impact on economic growth [2]. There has been a limited number of studies in Nigeria that analyze the relationship between debt and economic growth. Against this background, the paper investigates the relationship between public debt and economic growth in Nigeria. In addition, the study seeks to determine whether there is evidence of a linear impact of debt on growth and to identify this critical threshold beyond which debt impairs growth. Further, the paper attempts to clarify the impact of external and domestic debt on economic growth. The remainder of this study in divided into four section. The next section discussed the brief history of Nigerian dent profile. The second section discussed literature reviewed. The third section discussed the methodology and fourth and final section discussed empirical analysis and summary, conclusion and recommendations respectively.

Brief History of Nigerian Debt Profile:

The primary significant government acquiring of US \$1 billion from the global capital market (ICM) was alluded to as "Jumbo loan" expanding her external debt to $\$ 22$ billion. CBN (2016) the condition exacerbated somewhere in the range of 1981 and 1982 as different government offices and state governments turned to deficit budgeting financed through external loan sourced from private sources under stiffen conditions [3]. The Debt Management Office (DMO) yearly report and record mirrored a $13.8 \%$ fall of authority debt sources for the private obligation sources which rose again to a normal of $82 \%$. Exchange unfulfilled obligations developed before the part of the bargain a huge segment of the all external loan of the country. The Jumbo loan of 1987 was bolstered by the proclamation of declaration No 30 of the 1978 which restricted the outer credits that the Nigerian government could raise to $\$ 5$ billion.

Nigeria's external debt expanded such a great amount because of because excessive borrowing from worldwide agencies and nations at non concessional financing cost because of the decrease in oil profit from the late 70's and the rise of high exchange unpaid debts because of failure of the nation to either effectively deliver or foot the bills of importation of the required goods and services. Nigeria economic growth has been profoundly debilitating in spite of the tremendous outer debt profile before the year 2000 . Inside the $80 \mathrm{~s}$, the nation encountered the most monetary retreat with declining development rate, hyper swelling, and high joblessness rate, disequilibrium in equalization of installment, mechanical debauchery, poor framework and genuine outside obligation trouble. The poverty of the nation remained at $65 \%$ and the nation was named perhaps the weakest economy of the world on per capital premise.

The issue of Nigeria's public became significant as of late particularly preceding the time of the obligation absolution due to its extent and the sum, which was required to administration such obligations just as its specialist potential impacts on various working divisions of the economy particularly the financial area and the development of the economy on the loose. In 2005, Nigeria outer obligation was US\$34 billion (a likeness N2.7 trillion) of which about $\$ 28$ billion or $85 \%$ was owed to the Paris club of fifteen lender countries [4]. In spite of the fact that the administration effectively arranged obligation absolution and exit from the Paris club and London club of lenders bringing about the fall of outer obligation from N2.7 trillion in 2005 to under N451.46 billion in 2006, there was anyway a spike in the outside advance to N1.03 trillion in 2011 and N2. Ill trillion by 2015.

The government's expectation to obtain \$29.9 billion, would push Nigeria's outside debt stock which remained at $\$ 11.262$ billion as at June 2016 to $\$ 41.162$ billion following three years when the getting plan would have been completely executed.

\section{Literature Review}

\subsection{Theoretical Review}

Solow (1956) in the neoclassical development hypothesis, emphasis that domestic saving financing the aggregate investment with labour-augmenting technological change is exogenous in determining the equilibrium growth of per capita output [5]. However, the growth model is feasible in the closed economy where there is no interaction with the rest of the world. Mankiw, Romer and Weil (1992) studies stretch out the Solow-Swan model to incorporate human capital in the development model by holding the constant returns to scale in all inputs (diminishing returns to physical and human capital) [6]. Relatively speaking, small changes in resources devoted to physical and human capital may lead to large changes in output per worker. Krugman (1988) characterizes debt overhang as a circumstance in which the normal reimbursement of external debt misses the mark regarding the legally binding estimation of the obligation [7]. Likewise, with the abnormal state of debt stock effectively affecting economic growth, a nation would be looked with the high likelihood of encountering the debt overhang issue. Pattillo, Poirson, and Ricci (2002) added that if there is a few probability that, later on, debt will be bigger than the nation's reimbursement capacity the expected obligation administration cost will demoralize further household and remote venture [8]. As it were, huge debt weights press ventures since returns are limited through obligation administration installment by remote loan bosses. Claessens, Detragiache, Kanbur and Wickham (1997) opined that high obligations have a negative effect on the pace of venture and financial development due to disincentive, money stream and good peril impacts [9].

However, at a reasonable level of foreign borrowing, external debt could have a positive impact on investment and growth. The "Laffer Curve" describes the relationship between the face value of debt and investment. If the outstanding debt increases beyond a threshold level, the expected repayment begins to fall as a consequence of adverse effect. In other words, on the upward-sloping curve or 'good' section the implication is that an increase in the face value of debt is associated with an increase in expected repayment up to a threshold level. Along the 'bad' section of the "Laffer Curve", an increase in the face value of debt 
reduces expected payment

\subsection{Empirical Literature}

Previous scholars have tried to analyzed the impact of external debt on economic growth in Nigeria using variance decomposition and impulse response from Vector AutoRegression (VAR), and a time-series econometric model to test whether or not External Debt, Ratio of External debt to Exports and other economic control variables such as: Inflation, Real Exchange Rate and Public investment stimulate economic growth proxy by gross domestic product (GDP) growth rate. Ibi and Aganyi (2015) using the twostage data processing, the result reveals that causation between external debt and economic growth is weak in the Nigerian context and external debt could thus not be used to forecast improvement or slowdown in economic growth in Nigeria [10]. Hence, changes in GDP cannot be predicted with changes in external debt. The policy implication of the study is that most Nigerians contract debt for selfish reasons rather than for the promotion of economic growth. For debt to promote growth in Nigeria, fiscal discipline and high sense of responsibility in handling public funds should be the watchword of Nigerian leaders.

Karagol (2002) investigated the short-run and long-run relationships between economic growth and external debt service for Turkey during 1956-1996 have been investigated. The study employed a standard production function model analyzed using multivariate co-integration techniques. The Vector Auto regression estimates showed that there exists one Co-integration equation. It also revealed that debt service is negatively related to economic growth in the long-run. The causality test showed uni-directional causality between debt service and economic growth [11].

Clements, Nguyen and Bhattacharya (2003) examined the channels through which external debt affects growth in low income countries [12]. Their results suggest that the substantial reduction in the stock of external debt projected for highly indebted poor countries (HIPC) would directly increase per capita income growth by about $1 \%$ point per annum. Reductions in external debt service could also provide an indirect boost to growth through their effects on public investment. Malik, Hayat and Hayat (2010) explored the relationship between external debt and economic growth in Pakistan for the period of 1972-2005, using time series econometric technique [13]. Their result shows that external debt is negatively and significantly related to economic growth. The evidence suggests that increase in external debt will lead to decline in economic growth.

Debt-economic growth nexus also found significance among several scholars. Audu, (2004) examined the impact of external debt on economic growth and public investment in Nigeria from 1970-2002 [14]. The empirical investigation was done using the Co-integration test and Error Correction Method. The study shows that debt servicing pressure in the country has had a significant adverse effect on the growth process, and past debt accumulation negatively affect public investment. Ayadi, and Ayadi, (2008) examined the impact of the huge external debt, with its servicing requirements on economic growth of the Nigerian and South African economies [15]. The Neoclassical growth model which incorporates external debt, debt indicators, and some macroeconomic variables was employed and analyzed using both Ordinary Least Square (OLS) and Generalized Least Square (GLS) methods. Their finding revealed negative impact of debt and its servicing requirement on the economic growth of Nigeria and South Africa. Adesola, (2009) empirically investigated the effect of external debt service payment practices on the economic growth of Nigeria [16]. Ordinary Least Square method of multiple regression was used to examine how debt payment to multilateral financial creditors, Paris club creditors, London club creditors, Promissory Notes holders and other creditors relates to gross domestic product (GDP) and gross fixed capital formation (GFCF) using data from 1981-2004. The study provides evidence that debt payment to Paris club creditors and Promissory J. Bus. Manage. Adm. Notes holders are positively related to GDP and GFCF while debt payment to London club creditors and other creditors show a negative significant relation to GDP and GFCF. Ogunmuyiwa, (2011) examined whether external debt promotes economic growth in Nigeria using time-series data from 1970-2007 [17]. The regression equation was estimated using econometric techniques such as Augmented Dickey-Fuller test, Granger causality test, Johansen co-integration test and Vector Error Correction Method (VECM). The results revealed that causality does not exist between external debt and economic growth in Nigeria. Sulaiman and Azeez (2012) examine the effect of external debt on economic growth of Nigeria. Ordinary Least Squares (OLS), Augmented Dickey-Fuller (ADF) Unit Root test, Johansen Co-integration test and Error Correction Method (ECM) were employed in the empirical analysis [18]. The findings from the error correction method show that external debt has contributed positively to the Nigerian economy. The study recommends that government should ensure economic and political stability and external debt should be acquired largely for economic reasons rather than social or political reasons.

Adesola, (2009) focused on debt servicing and economic growth in Nigeria, using ordinary least square multiple regression method to determine whether debt payment to Multilateral Financial creditors, Paris Club creditors, London Club creditors, Promissory notes holders and Other creditors (Non-Paris Creditors) have inverse relationship with gross domestic product (GDP) and gross fixed capital formation at current prices (GFCF) from 1981 to 2004 [16]. The study revealed that debt payment to London Club creditors, Paris Club creditors, Promissory notes holders and other creditors have significant impact on the GDP and GFCF. Debt payment to Paris Club creditors and debt payment to promissory notes holders/are positively related to GDP and GFCF, while debt payment to London Club creditors and other creditors showed a negative significant relation to GDP and GFCF.

Ezeabasili, Isu, and Mojekwu, (2011) investigated the relationship between Nigeria's external debt and economic 
growth between 1975 and 2006 applying econometric analyses. The result of the error correction estimates revealed that external-debt has negative relationship with economic growth in Nigeria. They stated that Nigeria must be concerned about the absorptive capacity noting that consideration about low debt to GDP, low debt service/GDP capacity ratios should guide future debt negotiations [19].

Nwanne and Eze (2015) investigated the relationship between external public debt servicing and receipt and exchange rate fluctuations in Nigeria from 1981 to 2013 [20]. The findings of the study showed that external debt receipts and external debt servicing have positive short and long-run relationships with naira exchange rate fluctuations. The study concluded that whereas external public debt receipts affect exchange rate positively, external public debt servicing affects exchange rate negatively.

Hassan, Sule, and Abu (2015) examined the effect of government debt on economic growth in Nigeria between 1986 and 2013 - using the ordinary least square method [21]. The study revealed that the impact of government debt on economic growth over the period under review is insignificant - with external debt which has been enormous over the years contributing minimally to real gross domestic product. The findings of the study reveal that, if the course of consistent borrowing is not curbed, the economy will slump further: resorting to surplus budgeting, and igniting; increases in unemployment, decreases in total investment, falling reserves, increased exchange rate, higher inflation and consequently increased poverty. It is therefore recommended among others that borrowing should be a last recourse by the government to revitalize the economy, and if necessary, the loans should be sourced within the economy so that when the principal and interest on the loans are paid back, it will serve as a crowd-in-effect which in turn further accelerates economic activities in the country.

Ibi and Aganyi (2015) analysed the impact of external debt on economic growth in Nigeria. It uses the variance decomposition and impulse response from Vector AutoRegression (VAR) [10]. Based on the two-stage data processing, the result reveals that causation between external debt and economic growth is weak in the Nigerian context and external debt could thus not be used to forecast improvement or slowdown in economic growth in Nigeria. Hence, changes in GDP cannot be predicted with changes in external debt. For debt to promote growth in Nigeria, fiscal discipline and high sense of responsibility in handling public funds should be the watchword of Nigerian leaders.

Solomon (2016) investigated the impact of external debt on the Nigeria economy [22]. Data was collected from the secondary source while the regression and granger causality methods of analysis were applied. The outcome of the regression analysis showed that external debt and external debt service have negative relationship with GDP. The granger causality test shows that GDP has a unidirectional causal relationship with external debt service which runs from GDP to external debt service, uni-directional causality exists between external debt and GDP which runs from external debt to GDP. It recommends that external debt should largely be for economic reasons rather than social or political reasons as this would increase the productivity of the nation.

Matthew and Mordecai (2016) examined the impact of public debt on economic development of Nigeria using annual time series data spanning 1986 to 2014 [23]. The study employed the Augmented Dickey-Fuller test, Johansen cointegral ion test, Error Correction Method (ECM) and the Granger Causality test. The Johansen co-integration test results revealed the presence of a long-run relationship among the variables viz; external debt stock, domestic debt stock, external debt servicing, domestic debt servicing and economic development (proxied with GDP per capita) in Nigeria. The ECM results revealed that external debt stock and external debt servicing have insignificant negative relationship with economic development in Nigeria, however, domestic debt stock has a direct and significant relationship with economic development while domestic debt service payment was significant but inversely related to economic development in Nigeria. The study recommended that the government should reduce the level of external debt it accumulates overtime, but domestic debt accumulation would contribute significantly to the development of the economy.

Udoffia and Akpanah (2016) investigated the impact of external debt on economic growth in Nigeria. The issue was empirically examined using the cointegration test and the error correction test for Nigeria over the period 1980 to 2012. Findings from this study supported the traditional view between external debt and growth. Also the study found the non-existence of debt overhang problem for Nigeria. It is recommended from the study that development activities in Nigeria be financed through increased export earnings spearheaded by export led growth strategy as well as investment in human capital as these can be the best alternative to external debt in the long-run.

\section{Data and Methodology}

\subsection{Data Sample}

This study investigates the dynamic relationship between external debt and economic growth in Nigeria using annual data over the period of 1985 to 2017 representing a total of 30 observations. As a proxy for the economic growth, Gross Domestic Product, for external debt; Debt Service Payment, External debt, foreign exchange rate obtained from the Central Bank Statistical Bulletin (CBN).

\subsection{Model Specification}

This study employs a Vector Error Correction Model (VECM) that uses the derived from dynamic OLS overparamatisation was employed to analysis the relationship between external debt, Debt Service Payment, External debt, and economic in Nigeria in Nigeria. All the data series are transformed into the natural log form. Specifically, external debt service in the natural $\log$ form $\operatorname{lnDSPT}$ external debt represents 
$\operatorname{lnEXDT}$, exchange rate represents $\operatorname{lnEXR}$, in the natural $\log$ form represented. The first difference of their natural $\log$ values

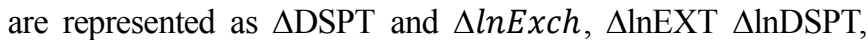
$\Delta \operatorname{lnEDTR}$ respectively. The first step is to investigate the order of integration of the variables used in the empirical study. The ADF (Augmented Dickey Fuller) test will be used in which the null hypothesis is $H_{o}: \beta=0$ i.e. $\beta$ has a unit root, and the alternative hypothesis is $H_{1}: \beta<0$. If the unit root tests confirm that at least some of the variables are I(1), then the next step would be to test if they are cointegrated, i.e. if they are bound by a long-run relationship. Cointegration exists between a set of non-stationary variables when a certain linear relationship of the series is stationary.

\subsection{Johansen Cointegration Test}

The test of the presence of long run equilibrium relationship among the variables using Johansen Cointegration test involves the identification of the rank of the $n$ by $n$ matrix $\Pi$ in the specification given by.

$$
\Delta Y_{t}=\beta+\sum_{i=1}^{k-1} \Gamma_{\mathrm{i}} \Delta Y_{t-1}+\prod Y_{t-k}+\varepsilon_{t}
$$

Where $Y_{t}$ is a column vector of the $n$ variables $\Delta$ is the difference operator, $\Gamma$ and $\Pi$ are the coefficient matrices, $\mathrm{k}$ denotes the lag length and $\beta$ is a constant. In the absence of cointegrating vector, $\Pi$ is a singular matrix, indicating that the cointegrating vector rank is equal to zero. Johansen cointegration test will involve two different likelihood ratio tests: the trace test ( $\lambda$ trace) and maximum eigen value test $(\lambda \max )$ shown in equations below:

$$
\begin{gathered}
J_{\text {trace }}=-T \sum_{i=r+1}^{n} \ln \left(1-\lambda_{\mathrm{i}}^{\wedge}\right) \\
J_{\max }=-T \ln \left(1-\lambda_{\mathrm{r}+1}^{\wedge}\right)
\end{gathered}
$$

Where $r$ the number of individual series, $T$ is the number of sample observations and $\lambda$ is the estimated eigen values. The trace test tests the null hypothesis of $r$ cointegrating vectors against the alternative hypothesis of $n$ cointegrating vectors. The maximum eigen value test $(\lambda \max )$, on the other hand, tests the null hypothesis of $r$ cointegrating vectors against the alternative hypothesis of $r+1$ cointegrating vectors. If the two series are found to be co-integrated, then Parsimonious error correction model (VECM) is appropriate to investigate causality relationship.

\subsection{Vector Error-Correction Modelling (VECM)}

The Short run equilibrium relationship is tested using Vector Error-Correction Model (VECM). VECM is built from specification over-parametization of dynamic OLS. The VECM analysis in this study is based on the function: GDP = f (DSPT EXDT, EXR). The VECM involving three cointegrated time series is set as:

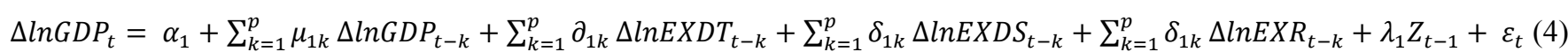

Where $Z_{t-1}$ is the error correction term obtained from the cointegration model. The error correction coefficients $\lambda_{1}$, $\lambda_{2}$ and $\lambda_{3}$ indicate the rate at which it corrects its previous period disequilibrium or speed of adjustment to restore the long-run equilibrium relationship. Hence, they are expected

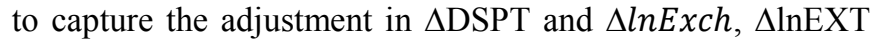
$\Delta \operatorname{lnDSPT} \Delta \operatorname{lnEDTR}$ towards the long-run equilibrium

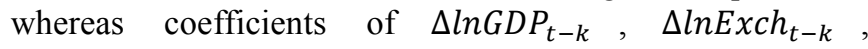
$\Delta \ln E X D T_{t-k}, \Delta \ln E X D S_{t-k}, \Delta \ln E X R_{t-k}$ are expected to capture the short-run dynamics of the model. This method of analysis permits us to test for the direction of causality, if it exists, as discussed next. Gujarati and Porter (2009) It is essential to appropriately specify the lag length $k$ for the PECM model; if $k$ is too small the model is misspecified and the missing variables create an omitted variables bias, while overparameterizing involves a loss of degrees of freedom and introduces the possibility of multicollinearity [25]. The study uses Akaike information criterion (AIC) to determine the optimum lag length.

\section{Empirical Results}

\subsection{Unit Root Tests Results}

To test the stationary properties of the data, ADF (Augmented Dickey Fuller) unit root tests is employed. The results for both the level and differenced variables are presented in Table 1 below:
Table 1. Stationarity Test.

\begin{tabular}{llllll}
\hline \multirow{3}{*}{ Variables } & \multicolumn{2}{l}{ Augmented Dickey Fuller (ADF) } & \\
\cline { 2 - 5 } & Levels & \multicolumn{3}{c}{ Ist Diff } & I(d) \\
\cline { 2 - 5 } & t-Stat. & p-value & t-stat. & p. value & \\
\hline InGDP & -1.633 & 0.3124 & -4.2146 & 0.0024 & $1(1)$ \\
InDSPT & 1.2166 & 0.7456 & -3.3456 & 0.0126 & $1(1)$ \\
InEXDT & -1.614 & 0.3468 & -3.5464 & 0.0156 & $1(1)$ \\
InEXR & -0.065 & 0.8467 & -4.2146 & 0.0046 & $1(1)$ \\
\hline
\end{tabular}

Table 2 Unit root test

**level of significance at $5 \% * * *$ level of significant at $1 \%$

Source: various computation from view 9

All the data are transformed into the natural log form. To determine the order of integration of the variables, the ADF (augmented Dickey-Fuller) test which the null hypothesis is $H_{0}=\beta=0$ (ie $\beta$ has a unit root), and the alternative hypothesis is $H_{l}=\beta<0$ are implemented. The results for the level and differenced variables are presented in table 2 .

The stationarity tests were performed first in levels and then in first difference to establish the presence of unit roots and the order of integration in all the variables. The results of the ADF stationarity tests for each variable show that the tests fail to reject the presence of unit root for data series in level, indicating that these variables are non-stationary in levels. The first difference results show that these variables are stationary at $1 \%$ and $5 \%$ significance level (integrated of order one 1(1)). As mentioned earlier, a linear combination of I (1) series could be I (0) if the series are cointegrated. We thus proceed to test for cointegration of the time series. 
Table 2. Lag Selection.

Endogenous variables: InGDP, InDSPT, InEXDT, InEXR

\begin{tabular}{|c|c|c|c|c|c|c|}
\hline Lag & $\log L$ & LR & FPE & AIC & SC & HQ \\
\hline 0 & -94.460 & NA & 0.000564 & 6.42567 & 6.60456 & 6.61024 \\
\hline 1 & 74.4617 & $261.20^{*}$ & $7.55 \mathrm{e}-0 *$ & -2.2126 & $-07656^{*}$ & $1.64354 *$ \\
\hline 2 & 93.46126 & 23.6024 & $1.26 \mathrm{E}-06$ & $-2.7646^{*}$ & 0.0567 & -1.04042 \\
\hline
\end{tabular}

Table 3: VAR lag order selection criteria

* indicates lag order selected by the criterion, LR: sequential modified LR test statistic (each test at 5\% level), FPE: Final prediction error, AIC: Akaike information criterion, SC: Schwarz information criterion, HQ; Hannan-Quinn information criterion.

From the table, our optimal using Akaike information criterion is lag 1.

\subsection{Johansen Cointegration}

This study next examined the null hypothesis of no cointegration among dependent and independents using Johansen Cointegration test. The results are presented in Table 2 below:

Table 3. Johansen Cointegration Test.

\begin{tabular}{|c|c|c|c|c|}
\hline \multicolumn{5}{|c|}{ Unrestricted Cointegration Rank Test (Trace) } \\
\hline Hypothesized & & Trace & 0.05 & \\
\hline No. of CE(s) & Eigenvalue & Statistic & Critical Value & Prob.** \\
\hline None* & 0.790287 & 65.8517 & 47.85613 & 0.0004 \\
\hline At most 1 & 0.331284 & 20.55328 & 29.79707 & 0.3861 \\
\hline At most 2 & 0.227377 & 8.883814 & 15.49471 & 0.3762 \\
\hline At most 3 & 0.047223 & 1.402848 & 3.841466 & 0.2362 \\
\hline
\end{tabular}

Trace test indicates 1 cointegrating eqn(s) at the 0.05 level

* denotes rejection of the hypothesis at the 0.05 level

***MacKinnon-Haug-Michelis (1999) p-values

\begin{tabular}{|c|c|c|c|c|}
\hline \multicolumn{5}{|c|}{ ricted Cointegration Rank Test (Maximum Eigenvalue) } \\
\hline Hypothesized & & Max-Eigen & 0.05 & \\
\hline No. of CE(s) & Eigenvalue & Statistic & Critical Value & Prob.** \\
\hline None * & 0.790287 & 45.29842 & 27.58434 & 0.0001 \\
\hline At most 1 & 0.331284 & 11.66947 & 21.13162 & 0.5805 \\
\hline At most 2 & 0.227377 & 7.480966 & 14.2646 & 0.4339 \\
\hline At most 3 & 0.047223 & 1.402848 & 3.841466 & 0.2362 \\
\hline
\end{tabular}

Max-eigenvalue test indicates 1 cointegrating eqn(s) at the 0.05 level

* denotes rejection of the hypothesis at the 0.05 level

**MacKinnon-Haug-Michelis (1999) p-values

*Level of significant at $10 \% * *$ level of significance at $5 \% * * *$ level of significant at $1 \%$

Source: computation from view 9

The results of the cointegration test, based on the Johansen cointegration approach are presented in table 3 . The author established lag 1 using akaike criterion (see table 2). Cointegration is tested on the long-run relationship between the dependent variable and independent variables. The table indicates that the test failed to accept the null hypothesis of no cointegration at $5 \%$ level of significance. Both the trace and maximum Eigen value suggest that there is a common stochastic trend and as such the number of free random walks has been reduced by one. Therefore GDP and independent variables have at least one common stochastic trend driving the relationship between them. The Johansen co-integration test shows this by cointegation test shows this by comparing the statistic values with the there is at most 1 cointegrating equation in the model with both trace and maximum eigen value suggest $5 \%$ significance level. This implies that an equilibrium relationship exists among the co-integrating variables. In addition, no matter the fluctuation in the shortrun, these variables have the tendency to return to this equilibrium path in the long-run.

Table 4. Normalized co-integration.

\begin{tabular}{llllll}
\hline variables & LGDP(-1) & LEXR(-1) & LEXDT(-1) & LDSPT(-1) & C \\
\hline Coefficient & 1 & 0.91437 & -0.51629 & -0.08637 & -2.5938 \\
& & $(0.0645)$ & $(0.1803)$ & $(0.2012)$ & -0.3056 \\
& {$[14.1668]$} & {$[-2.8638]$} & {$[-0.4294]$} & $(0.1125)$ \\
\hline
\end{tabular}

Source: computation from eviews 10 
Table 4 summarizes the range of parameters used to further analyse the long-run relationship between the variables and to capture the short-run deviations of the parameters from the long-run equilibrium by incorporating period lagged residuals. The results show that external debt service (DSPT) is negative and insignificantly related to GDP. External debt stock is negative and significantly related to GDP. It means that ceteris paribus, $1 \%$ increase in EXDT will lead to $0.15 \%$ decrease in GDP vice versa. The control variables exchange rate (EXR) are positive and significantly related to GDP. The error correction coefficient is negative, correctly signed and statistically significant with value of -0.3056 . This shows that the speed of adjustment of the model one to any short-run shock is approximately 30.56 percent per annum.

\subsection{The Granger-Causality Test}

Summary results of the Granger Causality test in Table 4 offer some interesting insights. For each of the variables, at least one channel of Granger causality is active.

Table 5. VECM Granger Causality Test Results.

\begin{tabular}{|c|c|c|c|}
\hline Null Hypothesis: & Obs & F-Statistic & Prob. \\
\hline LFXR does not Granger Cause LGDP & 30 & 9.62411 & 0.0008 \\
\hline LGDP does not Granger Cause LFXR & & 3.45248 & 0.0474 \\
\hline LEXDT does not Granger Cause LGDP & 30 & 0.0835 & 0.9202 \\
\hline LGDP does not Granger Cause LEXDT & & 1.07705 & 0.3559 \\
\hline LDSPT does not Granger Cause LGDP & 30 & 0.10464 & 0.901 \\
\hline LGDP does not Granger Cause LDSPT & & 2.10643 & 0.1427 \\
\hline LEXDT does not Granger Cause LFXR & 30 & 0.03694 & 0.9638 \\
\hline LDSPT does not Granger Cause LFXR & 30 & 0.16701 & 0.8471 \\
\hline LFXR does not Granger Cause LDSPT & & 1.99268 & 0.1574 \\
\hline LDSPT does not Granger Cause LEXDT & 30 & 6.66056 & 0.0048 \\
\hline LEXDT does not Granger Cause LDSPT & & 14.4895 & $7.00 \mathrm{E}-05$ \\
\hline
\end{tabular}

Source: E Views software

From the table above, it can be said that there is no causality relationship between external debt service and GDP. There is however nodirectional causality relationship with external debt and GDP running from GDP. Furthermore, there is no causality relationship between GDP and external reserve. The result however shows a no directional causality relationship between exchange rate and GDP.

\subsection{Discussion of Findings}

This study examines the impact of external debt stock and service on economic growth in Nigeria using Johansen approach to cointegration analysis and the direction of causality between the variables using VECM Granger causality framework over the period 1985 to 2017. The influence of external debt service and external debt stock on economic growth in the long run is negative and significant. Controlling for the influence of exchange rate, the study found exchange rate to be positive and statistically in influencing the economic growth in the long run. Comparatively, the results of this study generally supports some of the empirical findings of a number of studies from other economies.

Table 5 explains the results from Granger causality analysis: Findings reveal that there is no significant causality relationship between external debt service and GDP. There is however a no-directional causality relationship between external debt and GDP running from GDP.

\section{Conclusion}

\subsection{Summary of Findings}

Based on the overall results of the study, the following conclusions are reached.

1) Debt service payment has negative effect on Nigeria's GDP.

2) External debt has negative and significant effect on Nigeria's economic growth.

3) External debt has long-run significant effect on economic growth.

4) There is no directional causality relationship between external debt and economic growth while external debt service has no significant causal relationship with growth index.

\subsection{Recommendations}

From the findings and conclusion above, this study provide the following recommendations for policy makers, government agencies and appropriate authority for action

1) External debt should be used for the purpose for which it was borrowed and such should be on basic and infrastructural development that will help improve on the business environment and economic output making for ease of repayment.

2) Debt management policy should be properly initiated to reduce the negative effect of debt service on the economy as shown in the findings.

3) Efforts should be geared towards diversifying the economy and government revenue as this will help 
reduce the use of external loan to fund government projects.

4) There is need to strengthen the naira, therefore authorities should adopt policies that will encourage foreign investment and reduce demand for foreign good

5) Development activities in Nigeria should be financed through increased export earnings spearheaded by export-led-growth strategy as well as investment in human capital as these would be the best alternative to external debt in the longrun.

6) Policy-makers should reformulate the external debt management strategy to minimize sovereign risk through diversification of the external borrowing. This could potentially be achieved by reducing the dependency on one specific debt instrument or currency. Hence, the strategy will be effective if it is carried out in parallel with a comprehensive surveillance and debtmonitoring system.

\section{References}

[1] Mohd Dauda, S. N., Ahmad, A. H., \& Azman-Saini, W. N. W. (2013). Does external debt contribute to Malaysia economic growth?. Economic research-Ekonomska istraživanja, 26 (2), 51-68.

[2] Reinhart, C. M., \& Rogoff, K. S. (2010). Growth in a Time of Debt. American Economic Review, 100 (2), 573-78.

[3] Central Bank of Nigeria (CBN) Statistical Bulletin, various Issues.

[4] Emmanuel, O. O. (2012). An empirical analysis of the impact of public debt on economic growth; Evidence from Nigeria 1975-2005. Canadian Social Science, 8 (4), pp. 154-161.

[5] Solow, R. M. (1956). A contribution to the theory of economic growth. The quarterly journal of economics, 70 (1), 65-94.

[6] Mankiw, N. G., Romer, D., \& Weil, D. N. (1992). A contribution to the empirics of economic growth. The quarterly journal of economics, 107 (2), 407-437.

[7] Krugman, P. (1988). Financing vs. forgiving a debt overhang. Journal of development Economics, 29 (3), 253-268.

[8] Pattillo, C. A., Poirson, H., \& Ricci, L. A. (2002). External debt and growth (No. 2002-2069). International Monetary Fund.

[9] Claessens, S., Detragiache, E., Kanbur, R., \& Wickham, P. (1997). HIPCs' debt review of the issues. Journal of African Economies, 6 (2), 231-254.

[10] Ibi, E. E. and Aganyi, A. (2015), Impacts of external debt on economic growth in Nigeria: a VAR approach. Journal of Business Management and Administration, 3 (1), 1-5.
[11] Karagol, E. (2002). External debt and economic growth relationship using the simultaneous equations. Universitätsund Landesbibliothek Sachsen-Anhalt.

[12] Clements, M., Nguyen, T. Q., B. J., \& Bhattacharya, M. R. (2003). External debt, public investment, and growth in lowincome countries (No. 3-249). International Monetary Fund.

[13] Malik, S., Hayat, M. K., \& Hayat, M. U. (2010). External debt and economic growth: Empirical evidence from Pakistan. International Research Journal of Finance and Economics, 44 (44), 1450-2887.

[14] Audu, I. (2004). The impact of external debt on economic growth and public investment: The case of Nigeria. African Institute for Economic Development and Planning (IDEP).

[15] Ayadi, F. S., \& Ayadi, F. O. (2008). The impact of external debt on economic growth: A comparative study of Nigeria and South Africa. Journal of Sustainable Development in Africa, 10 (3), 234-264.

[16] Adesola, W. A. (2009). Debt servicing and economic growth in Nigeria: An empirical investigation. Global Journal of social sciences, 8 (2).

[17] Ogunmuyiwa, M. S. (2011). Does external debt promote economic growth in Nigeria. Current Research Journal of Economic Theory, 3 (1), 29-35.

[18] Sulaiman, L. A., \& Azeez, B. A. (2012). Effect of external debt on economic growth of Nigeria. Journal of Economics and Sustainable Development, 3 (8), 71-79.

[19] Ezeabasili, V. N., Isu, H. O., Mojekwu, J. N., (2011). Nigeria's external debt and economic growth: An error correction approach. International Journal of Business and Management. 6 (5), May.

[20] Nwanne, T. F. I. and Eze, O. R. (2015). Assessing the effect of external debt servicing and receipt on exchange rate in Nigeria. International Journal of Economics and Finance, 7 (9), pp. 278-286.

[21] Hassan, O. M., Sule, A., \& Abu, J. (2015). Implications of external debt on the Nigerian economy: Analysis of the dual gap theory. Journal of economics and sustainable development, 6 (13), 238-248.

[22] Solomon, O. (2016). The Impact of External Debt on the Nigerian Economy. www. independent, academia. Edu.

[23] Matthew, A. and Mordecai, B. D. (2016). The impact of public debt on economic development of Nigeria. Asian Research Journal of Arts \& Social Sciences, 1 (1), 1-16.

[24] Udoffia, D. T., \& Akpanah, E. A. (2016). An Assessment of the Impact of External Debt on Economic Growth of Nigeria. International Journal of Social Sciences, 10 (1), 1-20.

[25] Gujarati, D. N., \& Porter, D. (2009). Basic Econometrics Mc Graw-Hill International Edition. 